\title{
The Site of Action of Furosemide and Other Sulfonamide Diuretics in the Dog*
}

\author{
Wadi Suki, Floyd C. Rector, Jr., and Donald W. Seldin $\dagger$ \\ (From the Department of Internal Medicine, the University of Texas Southwestern Medical \\ School, Dallas, Texas)
}

The discovery of the countercurrent multiplier system as the mechanism responsible for the concentration and dilution of the urine has provided a framework for the identification of the site of action of diuretic drugs. Agents that act at a single anatomic site in the nephron can be expected to alter the pattern of urine flow in a predictable way. A drug that acts solely in the proximal convoluted tubule, by causing the delivery of increased amounts of filtrate to the loop of Henle and the distal convolution, would augment the clearance of solute-free water $\left(\mathrm{C}_{\mathrm{H}_{2} \mathrm{O}}\right)$ during water diuresis and the reabsorption of solute-free water $\left(\mathrm{T}^{\mathrm{c}} \mathrm{H}_{2} \mathrm{O}\right)$ during water restriction. In contrast, drugs that inhibit sodium reabsorption in Henle's loop would impair both $\mathrm{C}_{\mathrm{H}_{2} \mathrm{O}}$ and $\mathrm{T}^{\mathrm{c}} \mathrm{H}_{2} \mathrm{O}$. Finally, drugs that act only in the distal tubule would reduce $\mathrm{C}_{\mathrm{H}_{2} \mathrm{O}}$ but not $\mathrm{T}^{\mathrm{c}} \mathrm{H}_{2} \mathrm{O}$ (1).

It is possible, however, that a diuretic drug might inhibit sodium reabsorption at multiple sites. Under such circumstances, localization of the areas of the nephron where the drug acts is far more difficult, since the effects of action in one segment might alter or obscure the effects on another.

A new sulfonamide diuretic, furosemide, 4-chloro- $N$ - (2-furylmethyl)-5-sulfonylanthranilic acid (2), offers several advantages in the study of localization of action: a) it is extremely potent, and therefore produces large effects; and $b$ ) its duration of action is brief, thereby facilitating multiple studies during a single experiment. A study

* Submitted for publication February 18, 1965 ; accepted May 17, 1965.

Supported in part by grants 5 TI AM-5028 and 5 TI HE-5469 from the National Institutes of Health, U. S. Public Health Service. 260.

A preliminary report appeared in Clin. Res. 1964, 12,

$\dagger$ Address requests for reprints to Dr. Donald W. Seldin, University of Texas Southwestern Medical School, Dept. of Internal Medicine, Dallas, Texas 75235. of furosemide was, therefore, undertaken to ex plore its effects on water excretion during hydration and hydropenia, and on potassium excretion during potassium loading. In addition, the diuretic effect of furosemide was compared to three other sulfonamide diuretics: chlorothiazide, chlorthalidone, and benzhydroflumethiazide.

The conventional sulfonamide diuretics resulted in the excretion of about $10 \%$ of filtered sodium and inhibited $\mathrm{C}_{\mathrm{H}_{2} \mathrm{O}}$ without decreasing $\mathrm{T}^{\mathbf{c}}{ }_{\mathrm{H}_{2} \mathrm{O}}$. In contrast, as much as $38 \%$ of filtered sodium was excreted during furosemide diuresis, and both $\mathrm{C}_{\mathrm{H}_{2} \mathrm{O}}$ and $\mathrm{T}^{\mathbf{c}} \mathrm{H}_{2} \mathrm{O}$ were inhibited. None of the diuretics had an inhibitory effect on potassium secretion. The effects of the conventional sulfonamide diuretics can be explained by a single site of action distal to the loop of Henle. In contrast, furosemide clearly has a potent effect in the ascending limb of Henle's loop and probably in the proximal convoluted tubule as well.

\section{Methods}

A total of 50 experiments was performed on 40 dogs. All dogs were fasted overnight before each study. Mild pentothal anesthesia was induced to facilitate the insertion of an indwelling urethral catheter; the dogs were then allowed to awaken. The experiments were divided as follows.

Water diuresis. In 18 experiments on 13 of the dogs water diuresis was induced by the administration of 50 $\mathrm{ml}$ of water per $\mathrm{kg}$ body weight via a nasogastric tube and maintained by the continuous infusion of $2.5 \%$ dextrose solution at $10 \mathrm{ml}$ per minute. When water diuresis was well established, two to four control urine samples were collected.

Since an increase in sodium excretion during water diuresis results in an increased formation of free water (3) and hence will obscure any inhibitory effect of a drug on this latter function, the normal relationship between osmolar clearance $\left(\mathrm{C}_{\mathrm{osm}}\right.$ ) and $\mathrm{C}_{\mathrm{H}_{2} \mathrm{O}}$ was first defined. The increase in $\mathrm{C}_{\text {osm }}$ was accomplished in $4 \mathrm{ex}$ periments by the infusion of 10 to $20 \mathrm{ml}$ per minute of $0.1 \mathrm{M}$ $\mathrm{NaCl}$. In the remaining 14 experiments the control period was followed by the intravenous administration of 
the diuretic drug to be studied- 0.5 to $5 \mathrm{mg}$ per $\mathrm{kg}$ body weight furosemide ( 7 experiments), 2 to $5 \mathrm{mg}$ per $\mathrm{kg}$ body weight chlorthalidone (3 experiments), $2 \mathrm{mg}$ per $\mathrm{kg}$ body weight benzhydroflumethiazide ( 3 experiments), and $25 \mathrm{mg}$ per $\mathrm{kg}$ body weight chlorothiazide (1 experiment). Urine samples were then collected for several more periods. Preliminary experiments disclosed that under the conditions of our experiments $0.5 \mathrm{mg}$ furosemide per $\mathrm{kg}$ body weight elicited a maximal natriuretic response that was not augmented by a tenfold increase in drug dosage. The amounts of chlorthalidone, benzhydroflumethiazide, and chlorothiazide injected were also doses that produced maximal levels of sodium excretion.

In early experiments the brisk diuresis induced by furosemide appeared to reduce extracellular fluid (ECF) volume and stimulate antidiuretic hormone $(\mathrm{ADH})$, which would influence free water excretion independent of any direct effect of the drug on free water formation. To obviate this possibility ECF volume was replenished during furosemide diuresis by infusing $0.1 \mathrm{M} \mathrm{NaCl}$ at a rate that was varied every minute to equal the rate of urine flow, and thereby prevent either underexpansion or overexpansion of extracellular volume.

Hydropenia. In 25 experiments on 22 dogs water was withdrawn 24 hours before each experiment. On the day of the experiment $5 \mathrm{U}$ of vasopressin in oil was injected intramuscularly, followed 2 hours later by $22 \mathrm{mU}$ per $\mathrm{kg}$ body weight aqueous vasopressin intravenously and 50 $\mathrm{mU}$ per $\mathrm{kg}$ per hour subsequently.

To examine critically the effect of the diuretic drugs on the relationship between $\mathrm{T}^{\mathrm{c}} \mathrm{H}_{2} \mathrm{O}$ and $\mathrm{C}_{\mathrm{osm}}$, the normal relationship between these two variables was established in each dog for comparison. This was accomplished by infusing 2 to $5 \% \mathrm{NaCl}$ solutions at 4 to $10 \mathrm{ml}$ per minute and collecting several periods at a wide range of urine flow. Because of the short duration of furosemide action, it was possible to define the normal relationships of $\mathrm{C}_{\mathrm{osm}}$ to $\mathrm{T}_{\mathrm{H}_{2} \mathrm{O}}^{\mathrm{c}}$ in these experiments by commencing the infusion of hypertonic saline following the termination of furosemide action. In the experiments involving the other longer acting diuretics, however, it was necessary to first induce a hypertonic saline diuresis; the diuretic drugs were then given at the termination of the saline diuresis. Furosemide was given in 5 experiments, benzhydroflumethiazide in 5 experiments, chlorthalidone in 5 experiments, and chlorothiazide in 1 experiment. The doses of the diuretic agents were the same as those given during water diuresis. To prevent a fall in $\mathrm{T}^{\mathbf{c}}{ }_{\mathrm{H}_{2} \mathrm{O}}$ due to salt depletion (4), $0.9 \% \mathrm{NaCl}$ was infused at a rate equal to urine flow for the duration of drug action in every experiment.

Potassium secretion. The effect of diuretics on tubular secretion of potassium was studied under conditions designed to stimulate maximal secretion, so as to obviate the masking effect of increased sodium delivery and thereby facilitate the detection of any inhibitory influence of the drug. Accordingly, 7 dogs were prepared in the manner described by Berliner, Kennedy, and Hilton (5). The dogs were fed 10 to $12 \mathrm{~g} \mathrm{KCl}$ daily for 1 week. On the day of the experiment $0.06 \mathrm{M} \mathrm{KFe}(\mathrm{CN})_{B}$ was infused at 2 to $3 \mathrm{ml}$ per minute ( 480 to $720 \mu \mathrm{Eq}$ per minute) for at least 90 minutes after which two to three control periods were collected and this was followed by the administration of the diuretic drug to be studied : 4 dogs received $2 \mathrm{mg}$ per $\mathrm{kg}$ body weight furosemide, 2 dogs received chlorothiazide $25 \mathrm{mg}$ per $\mathrm{kg}$, and $1 \mathrm{dog}$ received $5 \mathrm{mg}$ per $\mathrm{kg}$ chlorthalidone. Since the diuretic-induced increase in sodium excretion might secondarily increase potassium excretion, an inhibitory effect of a diuretic on potassium secretion might be masked. It was possible to compare the effect of increased sodium excretion on potassium excretion in the absence of diuretic drug effect by the infusion of $5 \% \mathrm{NaCl}$ at $4 \mathrm{ml}$ per minute in 2 dogs after recovery from furosemide action.

The glomerular filtration rate (GFR) and renal plasma flow (RPF) were measured by the clearance of inulin and para-aminohippurate $(\mathrm{PAH})$, respectively. Inulin was determined by the method of Walser, Davidson, and Orloff (6), PAH by the method of Smith and co-workers (7), sodium and potassium by internal standard flame photometry, freezing point by a Fiske osmometer, ammonia by a modified Conway microdiffusion method (8), and urine $\mathrm{pH}$ and titratable acid by a Beckman model $\mathrm{G}$ $\mathrm{pH}$ meter. $\mathrm{C}_{\mathrm{osm}}, \mathrm{C}_{\mathrm{H}_{2} \mathrm{O}}$, and $\mathrm{T}^{\mathrm{c}} \mathrm{H}_{2} \mathrm{O}$ were computed in the usual fashion.

\section{Results}

Onset and duration of action. All the diuretics studied appeared to have a rapid onset of action as evidenced by an increased rate of urine flow beginning within 1 to 2 minutes after the start of the intravenous administration. Whereas furosemide action reached a peak in 30 minutes and declined to a minimum in about 60 minutes, the remaining three diuretics exhibited more prolonged action that lasted several hours.

Hemodynamics. Tables I and II list the GFR before and after diuretic administration. During antidiuresis, the administration of furosemide resulted in a transient rise in 3 of 5 studies (Table I, experiments $1,3,4)$. This is also evident in the data of Heidland, Klütsch, and Suzuki in man (9). This temporary increase in GFR does not appear to be a pharmacologic effect of the drug, but is more likely a result of washout of inulin in the dead space of the urinary tract. In all experiments during water diuresis (Table II), the GFR remained constant or fell during the first diuretic period after furosemide administration.

In only 2 of 11 studies (Table I, experiments 6 and 8) did the other sulfonamide diuretics produce a rise in GFR during antidiuresis. In the remaining 9 studies the GFR remained unchanged or fell. Doubtless the smaller diuretic action of these 
TABLE I

Glomerular filtration rates before and after the administration of diuretics during antidiuresis in individual experiments

\begin{tabular}{|c|c|c|c|c|c|c|c|c|c|}
\hline \multirow[b]{2}{*}{ Diuretic } & \multirow{2}{*}{$\begin{array}{c}\text { Experi- } \\
\text { ment } \\
\text { no. }\end{array}$} & \multicolumn{4}{|c|}{ Control periods } & \multicolumn{4}{|c|}{ Experimental periods } \\
\hline & & 1 & 2 & 3 & 4 & 1 & 2 & 3 & 4 \\
\hline & & \multicolumn{4}{|c|}{$m l / m i n$} & \multicolumn{4}{|c|}{$m l / m i n$} \\
\hline Furosemide & $\begin{array}{l}1 \\
2 \\
3 \\
4 \\
5\end{array}$ & $\begin{array}{l}79.2 \\
48.7 \\
96.0 \\
75.8 \\
87.4\end{array}$ & $\begin{array}{l}79.8 \\
47.6 \\
70.8 \\
70.1 \\
79.9\end{array}$ & $\begin{array}{l}72.7 \\
40.6 \\
72.5 \\
74.6 \\
77.6\end{array}$ & $\begin{array}{l}89.1 \\
44.1 \\
76.7 \\
68.7\end{array}$ & $\begin{array}{r}112.3 \\
43.2 \\
81.8 \\
78.8 \\
60.4\end{array}$ & $\begin{array}{l}69.0 \\
40.0 \\
61.1 \\
61.6 \\
57.8\end{array}$ & $\begin{array}{l}81.9 \\
37.9 \\
51.5 \\
63.7\end{array}$ & $\begin{array}{r}100.3 \\
34.4 \\
\\
68.0\end{array}$ \\
\hline $\begin{array}{l}\text { Benzhydroflu- } \\
\text { methiazide }\end{array}$ & $\begin{array}{r}6 \\
7 \\
8 \\
9 \\
10\end{array}$ & $\begin{array}{r}109.0 \\
53.4 \\
61.6 \\
75.1 \\
113.6\end{array}$ & $\begin{array}{r}105.2 \\
48.9 \\
55.0 \\
80.2 \\
120.5\end{array}$ & $\begin{array}{r}110.4 \\
53.2 \\
56.6\end{array}$ & $\begin{array}{r}112.7 \\
51.9\end{array}$ & $\begin{array}{r}126.1 \\
49.7 \\
62.2 \\
52.5 \\
117.2\end{array}$ & $\begin{array}{r}111.9 \\
57.9 \\
53.4 \\
63.0 \\
109.4\end{array}$ & $\begin{array}{r}110.3 \\
56.5 \\
64.7 \\
83.1 \\
102.0\end{array}$ & $\begin{array}{r}125.3 \\
55.6\end{array}$ \\
\hline Chlorothiazide & 11 & 87.7 & & & & 74.9 & 57.1 & 61.0 & \\
\hline Chlorthalidone & $\begin{array}{l}12 \\
13 \\
14 \\
15 \\
16\end{array}$ & $\begin{array}{r}100.5 \\
94.8 \\
68.9 \\
58.1 \\
71.9\end{array}$ & $\begin{array}{r}100.3 \\
94.7 \\
64.0 \\
57.3 \\
76.2\end{array}$ & $\begin{array}{l}97.1 \\
90.8 \\
64.3 \\
53.3 \\
74.7\end{array}$ & $\begin{array}{l}95.2 \\
63.6 \\
55.2 \\
74.2\end{array}$ & $\begin{array}{l}84.6 \\
81.0 \\
47.5 \\
50.5 \\
62.6\end{array}$ & $\begin{array}{l}79.4 \\
86.3 \\
54.4 \\
47.1 \\
62.1\end{array}$ & $\begin{array}{l}84.9 \\
92.8 \\
54.4 \\
45.8 \\
63.8\end{array}$ & $\begin{array}{l}46.5 \\
62.7\end{array}$ \\
\hline
\end{tabular}

agents as compared with furosemide elicited less of a washout effect. In all 7 studies involving chlorthalidone, chlorothiazide, and benzhydroflumethiazide during water diuresis (Table II) GFR was constant or fell during the initial diuretic period. There was a tendency with all the diuretics studied, both during antidiuresis and water diuresis, for the GFR to fall during the later periods. This could not be entirely attributed to salt depletion or hypotension, since salt was administered at a rate sufficient to replenish urinary losses, and blood pressure was constant throughout.

Potency. When potency was expressed in terms of the per cent of the glomerular filtrate and the filtered sodium excreted under the impact of a diuretic drug, furosemide clearly was the most potent diuretic (Table III). Furosemide resulted in the excretion of an average of approximately $20 \%$ of the filtered sodium, whereas the average natriuresis with the other diuretics was only $10 \%$. Al-

TABLE II

Glomerular filtration rates before and after the administration of diuretics during water diuresis in individual experiments

\begin{tabular}{|c|c|c|c|c|c|c|c|c|}
\hline \multirow[b]{2}{*}{ Diuretic } & \multirow{2}{*}{$\begin{array}{c}\text { Experi- } \\
\text { ment } \\
\text { no. }\end{array}$} & \multicolumn{3}{|c|}{ Control periods } & \multicolumn{4}{|c|}{ Experimental periods } \\
\hline & & 1 & 2 & 3 & 1 & 2 & 3 & 4 \\
\hline & & \multicolumn{3}{|c|}{$\mathrm{ml} / \mathrm{min}$} & \multicolumn{4}{|c|}{$\mathrm{ml} / \mathrm{min}$} \\
\hline Furosemide & $\begin{array}{l}1 \\
2 \\
3 \\
4 \\
5 \\
6 \\
7\end{array}$ & $\begin{array}{r}92.5 \\
143.4 \\
79.1 \\
109.0 \\
90.2 \\
61.6 \\
70.0\end{array}$ & $\begin{array}{r}96.1 \\
136.9 \\
73.4 \\
117.6 \\
94.0 \\
56.0 \\
70.6\end{array}$ & $\begin{array}{r}93.1 \\
118.6 \\
61.5\end{array}$ & $\begin{array}{r}94.5 \\
136.1 \\
66.3 \\
97.4 \\
91.5 \\
57.7 \\
70.6\end{array}$ & $\begin{array}{r}101.3 \\
126.4 \\
71.2 \\
110.2 \\
72.3 \\
54.1 \\
68.0\end{array}$ & $\begin{array}{r}84.4 \\
110.4 \\
65.6 \\
99.6 \\
68.4 \\
56.1 \\
63.5\end{array}$ & $\begin{array}{r}72.0 \\
67.8 \\
104.0 \\
55.7 \\
55.7 \\
64.1\end{array}$ \\
\hline $\begin{array}{c}\text { Benzhydroflu- } \\
\text { methiazide }\end{array}$ & $\begin{array}{r}8 \\
9 \\
10\end{array}$ & $\begin{array}{r}70.6 \\
103.7 \\
74.5\end{array}$ & $\begin{array}{l}68.8 \\
70.6\end{array}$ & & $\begin{array}{r}68.6 \\
105.2 \\
69.8\end{array}$ & $\begin{array}{l}62.9 \\
97.5 \\
68.3\end{array}$ & $\begin{array}{l}63.1 \\
92.5\end{array}$ & $\begin{array}{l}65.1 \\
96.9\end{array}$ \\
\hline Chlorothiazide & 11 & 116.6 & 129.8 & & 93.0 & 100.9 & & \\
\hline Chlorthalidone & $\begin{array}{l}12 \\
13 \\
14\end{array}$ & $\begin{array}{l}83.7 \\
67.6 \\
81.7\end{array}$ & $\begin{array}{l}87.2 \\
66.5 \\
74.5\end{array}$ & & $\begin{array}{l}86.5 \\
62.7 \\
73.5\end{array}$ & $\begin{array}{l}81.9 \\
60.1 \\
64.8\end{array}$ & $\begin{array}{l}91.5 \\
66.1 \\
68.2\end{array}$ & $\begin{array}{l}93.9 \\
64.2 \\
58.8\end{array}$ \\
\hline
\end{tabular}


TABLE III

Comparison of the potency of the diuretics studied

\begin{tabular}{|c|c|c|c|c|c|}
\hline \multirow[b]{2}{*}{ Diuretic } & & \multicolumn{2}{|c|}{ Water diuresis } & \multicolumn{2}{|c|}{ Antidiuresis } \\
\hline & & $\frac{\mathrm{V}}{\mathrm{GFR}} \times 100 *$ & $\frac{\mathrm{C}_{\mathrm{Na}}}{\mathrm{GFR}} \times 100 \dagger$ & $\frac{\mathrm{V}}{\mathrm{GFR}} \times 100 *$ & $\frac{\mathrm{C}_{\mathrm{Na}}}{\mathrm{GFR}} \times 100 \dagger$ \\
\hline Furosemide & $\begin{array}{l}\text { Range } \\
\text { Mean } \pm S D\end{array}$ & $\begin{array}{l}19-45 \\
30 \pm 9.5\end{array}$ & $\begin{array}{l}11-33 \\
21 \pm 7.6\end{array}$ & $\begin{array}{c}9-39 \\
22 \pm 9.2\end{array}$ & $\begin{array}{c}8-38 \\
20 \pm 9.4\end{array}$ \\
\hline $\begin{array}{l}\text { Benzhydroflu- } \\
\text { methiazide }\end{array}$ & $\begin{array}{l}\text { Range } \\
\text { Mean } \pm \text { SD }\end{array}$ & $\begin{array}{l}15-24 \\
19 \pm 5.7\end{array}$ & $\begin{array}{l}6-9 \\
8 \pm 1.7\end{array}$ & $\begin{array}{l}4-7 \\
5 \pm 2.0\end{array}$ & $\begin{array}{l}6-11 \\
8 \pm 2.0\end{array}$ \\
\hline Chlorothiazide & & 13 & 6 & 7 & 10 \\
\hline Chlorthalidone & $\begin{array}{l}\text { Range } \\
\text { Mean } \pm S D\end{array}$ & $\begin{array}{l}16-24 \\
19 \pm 4.1\end{array}$ & $\begin{array}{l}9-10 \\
10 \pm 0.8\end{array}$ & $\begin{array}{l}5-11 \\
8 \pm 2.3\end{array}$ & $\begin{array}{l}8-14 \\
11 \pm 2.4\end{array}$ \\
\hline
\end{tabular}

$* \frac{\mathrm{V}}{\mathrm{GFR}} \times 100=$ maximal urine flow attained as per cent of glomerular filtration rate.

$\dagger \frac{\mathrm{C}_{\mathrm{Na}}}{\mathrm{GFR}} \times 100=$ maximal sodium clearance as per cent of glomerular filtration rate, or maximal sodium excretion as per cent of filtered sodium.

though the percentage of the glomerular filtrate that was excreted after the various diuretics was always higher during water diuresis than during antidiuresis, the percentage of the filtered sodium excreted under these two conditions was virtually the same.

Free water clearance. In Figure 1, the effect of changes in $\mathrm{C}_{\mathrm{osm}}$ on $\mathrm{C}_{\mathrm{H}_{2} \mathrm{O}}$ in control dogs and dogs given diuretics is charted.

The infusion of hypotonic saline to control dogs resulted in marked increases in $\mathrm{C}_{\mathrm{H}_{2} \mathrm{O}}$ with only slight increases in $\mathrm{C}_{\mathrm{osm}}$. The maximal $\mathrm{C}_{\mathrm{H}_{2} \mathrm{O}}$ at- tained was about $14 \mathrm{ml}$ per minute at a $\mathrm{C}_{\text {osm }}$ of only about 3 to $5 \mathrm{ml}$ per minute. The results suggest that about $14 \mathrm{ml}$ per minute is a maximum for $\mathrm{C}_{\mathrm{H}_{2} \mathrm{O}}$, but this could not be rigorously established, owing to our inability to increase $\mathrm{C}_{\text {osm }}$ beyond about $8 \mathrm{ml}$ per minute despite massive hypotonic saline infusions, probably because hyponatremia per se promotes sodium reabsorption (10).

All diuretics lowered sharply the maximal $\mathrm{C}_{\mathrm{H}_{2} \mathrm{O}}$, which never exceeded about $50 \%$ of that attained with hypotonic saline alone, despite the enormously greater increase in sodium excretion. In-

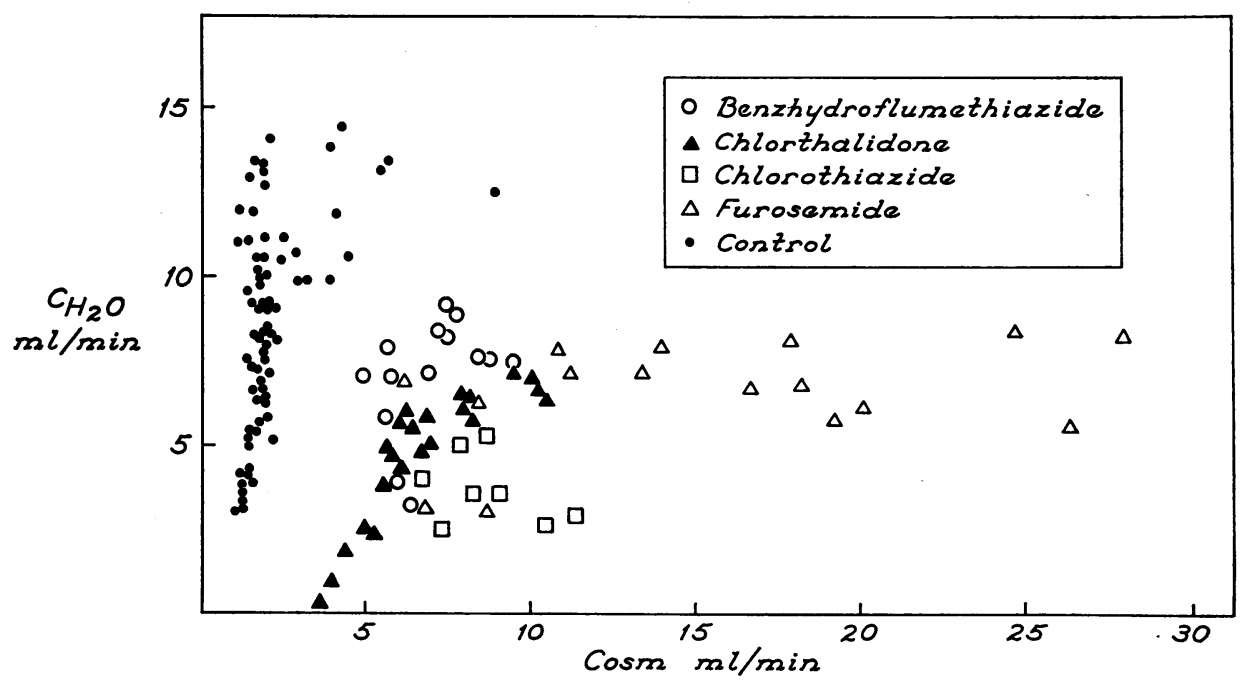

Fig. 1. The Relationship of Solute-free water Clearance ( $\mathrm{C}_{\mathrm{H}_{2} \mathrm{O}}$ ) to osmolar clearance ( $\mathrm{C}_{\text {osm }}$ ) DURING HYPOTONIC SALINE INFUSION (CONTROL) COMPARED TO THAT FOLLOWING THE ADMINISTRATION OF THE VARIOUS DIURETIC DRUGS. 
TABLE IV

Response of $\mathrm{C}_{\mathrm{H}_{2} \mathrm{O}}$ during furosemide diuresis: fall (experiment 1) or rise (experiment 2)*

\begin{tabular}{|c|c|c|c|c|c|c|c|c|}
\hline $\begin{array}{l}\text { Experi- } \\
\text { ment }\end{array}$ & Time & GFR & $\mathrm{V}$ & $\mathrm{U}_{\mathrm{osm}}$ & Cosm & $\mathrm{C}_{\mathrm{H}_{2} \mathrm{O}}$ & $\mathrm{UNaV}_{\mathrm{Na}}$ & UKV \\
\hline \multirow{5}{*}{1} & $\min$ & $m l / m i n$ & $m l / \min$ & $m O s m / L$ & $m l / \min$ & $m l / \min$ & $\mu E q / \min$ & $\mu E q / \min$ \\
\hline & \multicolumn{8}{|c|}{$\begin{array}{l}750 \mathrm{ml} \text { water by gastric tube; } 2.5 \% \text { dextrose at } 10 \mathrm{ml} \text { per minute; } 0.1 \mathrm{M} \mathrm{NaCl} \text { at } \\
\qquad 20 \mathrm{ml} \text { per minute }\end{array}$} \\
\hline & $\begin{array}{r}0-10 \\
10-20 \\
20-30\end{array}$ & $\begin{array}{l}93 \\
96 \\
93\end{array}$ & $\begin{array}{l}19.0 \\
18.5 \\
16.0\end{array}$ & $\begin{array}{l}85 \\
86 \\
75\end{array}$ & $\begin{array}{l}5.6 \\
5.4 \\
4.1\end{array}$ & $\begin{array}{l}13.4 \\
13.1 \\
11.9\end{array}$ & $\begin{array}{l}562 \\
561 \\
390\end{array}$ & $\begin{array}{l}72 \\
66 \\
67\end{array}$ \\
\hline & \multicolumn{8}{|c|}{30 Furosemide $0.5 \mathrm{mg}$ per $\mathrm{kg}$ iv; $0.1 \mathrm{M} \mathrm{NaCl}$ at $25 \mathrm{ml}$ per minute } \\
\hline & $\begin{array}{l}30-40 \\
40-50 \\
50-60\end{array}$ & $\begin{array}{r}95 \\
101 \\
84\end{array}$ & $\begin{array}{l}24.8 \\
21.9 \\
13.0\end{array}$ & $\begin{array}{l}205 \\
183 \\
134\end{array}$ & $\begin{array}{r}17.7 \\
14.0 \\
6.1\end{array}$ & $\begin{array}{l}7.1 \\
7.9 \\
6.9\end{array}$ & $\begin{array}{r}2,344 \\
1,789 \\
670\end{array}$ & $\begin{array}{r}150 \\
129 \\
79\end{array}$ \\
\hline \multirow[t]{4}{*}{2} & \multicolumn{8}{|c|}{$800 \mathrm{ml}$ water by gastric tube; $2.5 \%$ dextrose at $10 \mathrm{ml}$ per minute } \\
\hline & $\begin{array}{r}0-10 \\
10-20\end{array}$ & $\begin{array}{l}143 \\
137\end{array}$ & $\begin{array}{l}8.2 \\
7.3\end{array}$ & $\begin{array}{l}66 \\
82\end{array}$ & $\begin{array}{l}2.0 \\
2.2\end{array}$ & $\begin{array}{l}6.2 \\
5.1\end{array}$ & $\begin{array}{r}40 \\
100\end{array}$ & $\begin{array}{l}44 \\
50\end{array}$ \\
\hline & \multicolumn{8}{|c|}{20 Furosemide $2.0 \mathrm{mg}$ per $\mathrm{kg}$ iv; $0.1 \mathrm{M} \mathrm{NaCl}$ at $30 \mathrm{ml}$ per minute } \\
\hline & $\begin{array}{l}20-30 \\
30-30 \\
40-50 \\
50-60 \\
6070\end{array}$ & $\begin{array}{r}136 \\
126 \\
110 \\
72 \\
73\end{array}$ & $\begin{array}{r}33.0 \\
26.2 \\
25.0 \\
11.8 \\
9.9\end{array}$ & $\begin{array}{l}205 \\
210 \\
206 \\
199 \\
183\end{array}$ & $\begin{array}{r}24.6 \\
28.0 \\
19.2 \\
8.7 \\
6.8\end{array}$ & $\begin{array}{l}8.4 \\
8.2 \\
5.8 \\
3.1 \\
3.1\end{array}$ & $\begin{array}{r}3,033 \\
3,562 \\
2,342 \\
1,002 \\
765\end{array}$ & $\begin{array}{r}191 \\
196 \\
145 \\
73 \\
63\end{array}$ \\
\hline
\end{tabular}

${ }^{*} \mathrm{~V}=$ rate of urine flow; $\mathrm{U}_{\mathrm{osm}}=$ urinary solute concentration; $\mathrm{C}_{\mathrm{osm}}$ and $\mathrm{C}_{\mathrm{H}_{2} \mathrm{O}}=$ osmolar and solute-free water clearance; $U_{\mathrm{Na}} \mathrm{V}$ and $\mathrm{U}_{\mathrm{K}} \mathrm{V}=$ urinary sodium and potassium excretion.

deed, in the case of furosemide, $\mathrm{C}_{\text {osm }}$ increased from about 7 to $28 \mathrm{ml}$ per minute, whereas $\mathrm{C}_{\mathrm{H}_{2} \mathrm{O}}$ ranged from a value of $3 \mathrm{ml}$ per minute at a $\mathrm{C}_{\text {osm }}$ of $7 \mathrm{ml}$ per minute to a maximal value of only about $8 \mathrm{ml}$ per minute at a $\mathrm{C}_{\mathrm{osm}}$ of about $10 \mathrm{ml}$ per minute, where it remained constant, indicating that the maximum for $\mathrm{C}_{\mathrm{H}_{2} \mathrm{O}}$ is about $8 \mathrm{ml}$ per minute with this agent.

The administration of furosemide during water diuresis may be associated with a rise, no change, or a fall in $\mathrm{C}_{\mathrm{H}_{2} \mathrm{O}}$ (Figure 1, Table IV). This varied response is not the consequence of different degrees of inhibition of sodium transport in Henle's loop. Rather, the directional change in $\mathrm{C}_{\mathrm{H}_{2} \mathrm{O}}$ after furosemide will depend, as is evident from Figure 1 and Table IV, on the level of $\mathrm{C}_{\mathrm{H}_{2} \mathrm{O}}$ during the control period.

If $\mathrm{C}_{\mathrm{H}_{2} \mathrm{O}}$ is low (i.e., less than $8 \mathrm{ml}$ per minute) (Table IV, experiment 2), the administration of furosemide, by augmenting the delivery of sodium out of the more proximal portions of the nephron, will increase $\mathrm{C}_{\mathrm{H}_{2} \mathrm{O}}$ because the ability of the diluting segment to increase sodium reabsorption is not saturated even though its total capacity for sodium transport is reduced by almost half. $\mathrm{C}_{\mathrm{H}_{2} \mathrm{O}}$ will fall after furosemide if $\mathrm{C}_{\mathrm{H}_{2} \mathrm{O}}$ during the control pe- riod is high, since furosemide, by inhibiting sodium transport in the loop, will reduce $\mathrm{C}_{\mathrm{H}_{2} \mathrm{O}}$ formation to a maximal value of about $8 \mathrm{ml}$ per minute despite a great increase in sodium delivery (Table IV, experiment 1). Finally, it is clear from Figure 1 that if $\mathrm{C}_{\mathrm{H}_{2} \mathrm{O}}$ is about $8 \mathrm{ml}$ per minute during the control period, the increased delivery of sodium to the diluting segments cannot promote further sodium reabsorption; consequently, $\mathrm{C}_{\mathrm{H}_{2} \mathrm{O}}$ will re-

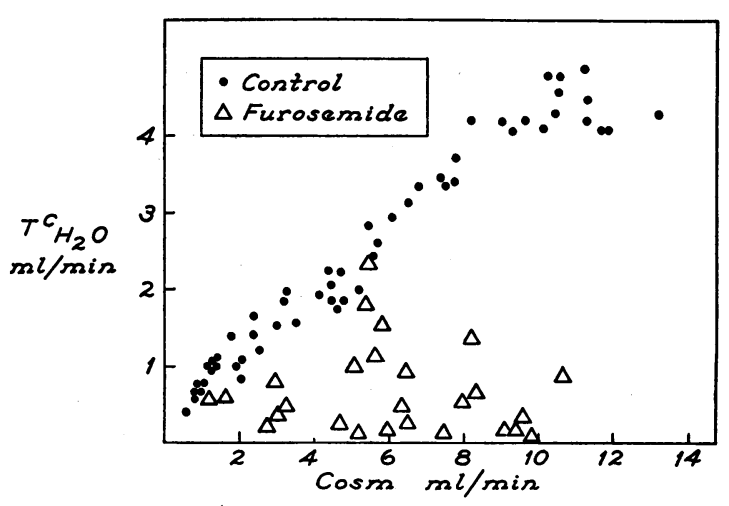

Fig. 2. THE RELATIONSHIP OF REABSORPTION OF SOLUTEFREE WATER $\left(\mathrm{T}^{\mathrm{c}} \mathrm{H}_{20} \mathrm{O}\right.$ ) TO Cosm DURING HYPERTONIC SALINE INFUSION (CONTROL) COMPARED TO THAT FOLLOWING ADMINISTRATION OF FUROSEMIDE. 


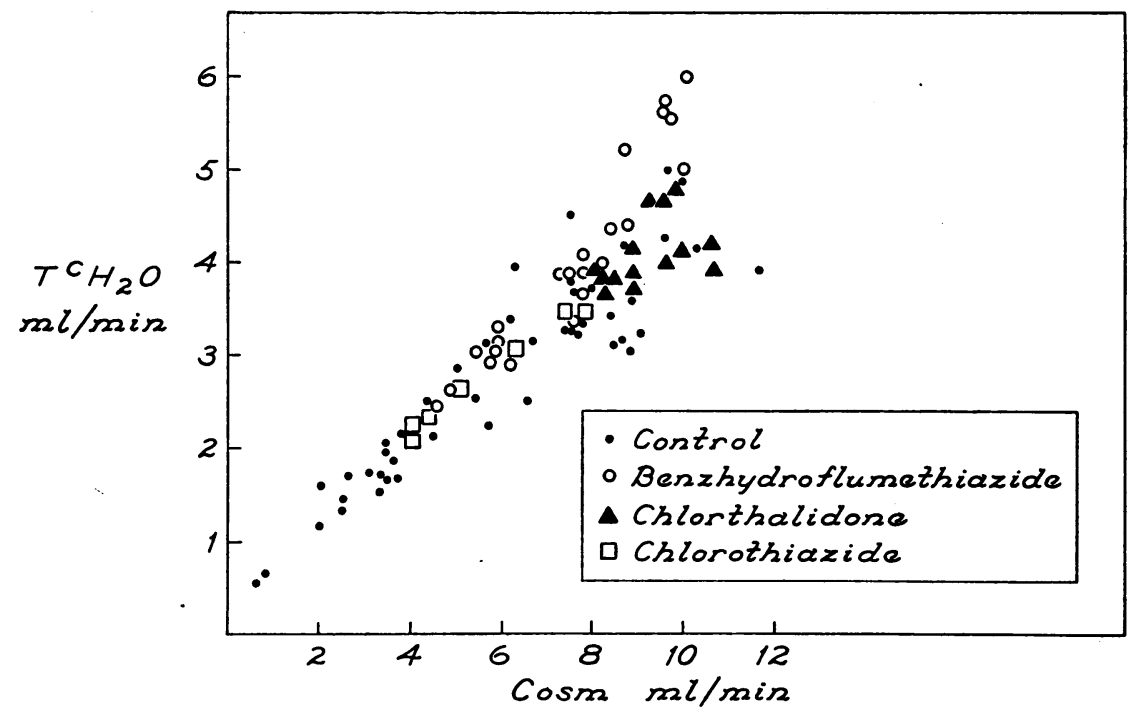

Fig. 3. The RELationship of $\mathrm{T}^{\mathrm{c}} \mathrm{H}_{20} \mathrm{O}$ TO Cosm DURING HYPERTONIC SALINE INFUSioN (CONTROL) COMPARED TO THAT FOLLOWING THE ADMINISTRATION OF BENZHYDROFLUMETHIAZIDE, CHLORTHALIDONE, AND CHLOROTHIAZIDE.

main unchanged as $\mathrm{C}_{\text {osm }}$ increases. Depending on the control level of $\mathrm{C}_{\mathrm{H}_{2} \mathrm{O}}$, furosemide can cause a fall, no change, or a rise in $\mathrm{C}_{\mathrm{H}_{2} \mathrm{O}}$.

Free water reabsorption. In Figure 2 are plotted the values for $\mathrm{T}^{\mathrm{c}} \mathrm{H}_{2} \mathrm{O}$ in dogs following furosemide administration as compared to $\mathrm{T}^{\mathrm{c}}{ }_{\mathrm{H}_{2} \mathrm{O}}$ formed by the same dogs during saline diuresis.
In control periods a rise in $\mathrm{C}_{\text {osm }}$ to about $14 \mathrm{ml}$ per minute was accompanied by a proportionate increase of $\mathrm{T}^{\mathrm{e}}{ }_{\mathrm{H}_{2} \mathrm{O}}$ to about $5 \mathrm{ml}$ per minute. After furosemide, however, $\mathrm{T}^{\mathrm{c}} \mathrm{H}_{2} \mathrm{O}$ at every level of $\mathrm{C}_{\mathrm{osm}}$ was markedly reduced.

Unlike furosemide, the other sulfonamide diuretics did not impair $\mathrm{T}^{\mathbf{c}_{\mathrm{H}_{2} \mathrm{O}}}$ formation. The re-

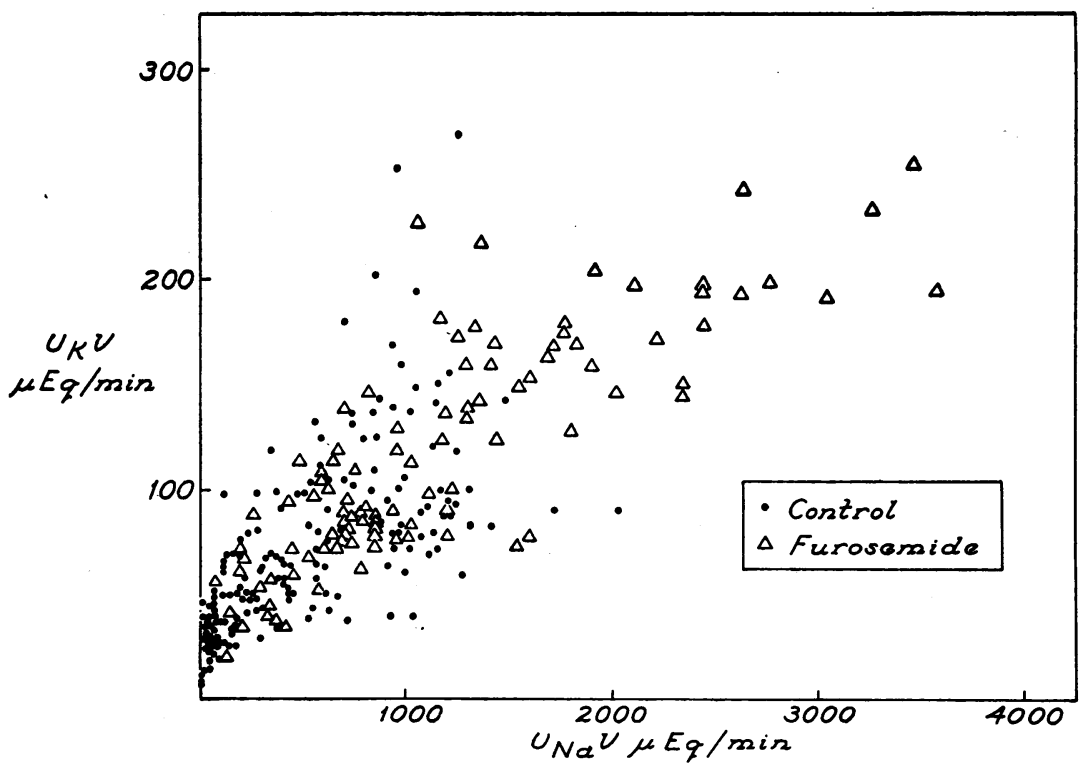

Fig. 4. The ChANGES IN POTASSIUM EXCRETION AS RELATED TO SODIUM EXCRETION BEFORE AND AFTER THE ADMINISTRATION OF FUROSEMIDE. 
TABLE V

The effect of furosemide and chlorthalidone on potassium secretion*

\begin{tabular}{|c|c|c|c|c|c|c|c|}
\hline \multirow[b]{2}{*}{ Dog no. } & \multirow[b]{2}{*}{ Time } & \multirow[b]{2}{*}{ GFR } & \multirow[b]{2}{*}{$\mathrm{V}$} & \multirow[b]{2}{*}{$\mathrm{U}_{\mathrm{Na}} \mathrm{V}$} & \multirow[b]{2}{*}{$\mathrm{UKV}$} & \multicolumn{2}{|c|}{ Serum } \\
\hline & & & & & & $\mathrm{Na}$ & $\mathbf{K}$ \\
\hline & $\min$ & $\mathrm{ml} / \mathrm{min}$ & $\mathrm{ml} / \mathrm{min}$ & $\mu E q / \min$ & $\mu E q / \min$ & $m E q / L$ & $m E q / L$ \\
\hline \multicolumn{8}{|c|}{ Dogs fed $10 \mathrm{~g} \mathrm{KCl}$ daily for 1 week; $0.06 \mathrm{M} \mathrm{K} \mathrm{Fe}_{4}(\mathrm{CN})_{6}$ at $2 \mathrm{ml}$ per minute } \\
\hline Med & $\begin{array}{r}0-30 \\
30-60 \\
60-90\end{array}$ & $\begin{array}{l}76 \\
75 \\
82\end{array}$ & $\begin{array}{l}0.6 \\
0.6 \\
0.6\end{array}$ & $\begin{array}{l}195 \\
184 \\
201\end{array}$ & $\begin{array}{l}444 \\
436 \\
458\end{array}$ & $\begin{array}{l}153 \\
155 \\
154\end{array}$ & $\begin{array}{l}5.9 \\
6.1 \\
5.9\end{array}$ \\
\hline \multicolumn{8}{|c|}{90 Furosemide $2.0 \mathrm{mg}$ per $\mathrm{kg}$ iv $; 0.9 \% \mathrm{NaCl}$ at rate equal to urine flow } \\
\hline & $\begin{array}{r}90-120 \\
120-150 \\
150-180\end{array}$ & $\begin{array}{r}45 \\
-\quad 59 \\
65\end{array}$ & $\begin{array}{l}6.5 \\
9.6 \\
5.3\end{array}$ & $\begin{array}{r}772 \\
1,246 \\
766\end{array}$ & $\begin{array}{l}568 \\
610 \\
531\end{array}$ & $\begin{array}{l}158 \\
154 \\
150\end{array}$ & $\begin{array}{l}5.8 \\
5.7 \\
6.2\end{array}$ \\
\hline \multicolumn{8}{|c|}{$1805 \% \mathrm{NaCl}$ at $4 \mathrm{ml}$ per minute } \\
\hline & $\begin{array}{l}180-210 \\
210-240 \\
240-270 \\
270300 \\
300-330\end{array}$ & $\begin{array}{l}74 \\
81 \\
86 \\
85 \\
90\end{array}$ & $\begin{array}{l}3.4 \\
4.0 \\
5.1 \\
6.1 \\
6.6\end{array}$ & $\begin{array}{r}527 \\
736 \\
1,036 \\
1,290 \\
1,417\end{array}$ & $\begin{array}{l}454 \\
533 \\
612 \\
669 \\
678\end{array}$ & $\begin{array}{l}153 \\
156 \\
164 \\
162 \\
158\end{array}$ & $\begin{array}{l}6.3 \\
6.8 \\
6.8 \\
7.0 \\
7.0\end{array}$ \\
\hline \multirow[t]{3}{*}{ No. 25} & $\begin{array}{r}0-15 \\
15-30 \\
30-45\end{array}$ & $\begin{array}{l}76 \\
69 \\
71\end{array}$ & $\begin{array}{l}4.0 \\
3.9 \\
4.1\end{array}$ & $\begin{array}{l}94 \\
85 \\
96\end{array}$ & $\begin{array}{l}536 \\
528 \\
556\end{array}$ & $\begin{array}{l}149 \\
150 \\
150\end{array}$ & $\begin{array}{l}6.5 \\
6.5 \\
6.5\end{array}$ \\
\hline & 45 & \multicolumn{6}{|c|}{$\begin{array}{l}\text { Chlorthalidone } 5 \mathrm{mg} \text { per } \mathrm{kg} \text { iv and } 5 \mathrm{mg} \text { per } \mathrm{kg} \text { per hour } ; 0.9 \% \mathrm{NaCl} \text { at } \\
\text { rate equal to urine flow }\end{array}$} \\
\hline & $\begin{array}{c}45-60 \\
60-75 \\
75-90 \\
90-105 \\
105-120 \\
120-135\end{array}$ & $\begin{array}{l}53 \\
69 \\
66 \\
66 \\
62 \\
66\end{array}$ & $\begin{array}{l}6.8 \\
8.5 \\
8.7 \\
8.1 \\
7.8 \\
7.1\end{array}$ & $\begin{array}{l}461 \\
602 \\
640 \\
570 \\
531 \\
492\end{array}$ & $\begin{array}{l}579 \\
653 \\
630 \\
620 \\
624 \\
658\end{array}$ & $\begin{array}{l}150 \\
148 \\
147 \\
146 \\
147 \\
145\end{array}$ & $\begin{array}{l}6.3 \\
6.0 \\
6.2 \\
6.4 \\
6.6 \\
6.9\end{array}$ \\
\hline
\end{tabular}

* See Table IV for abbreviations.

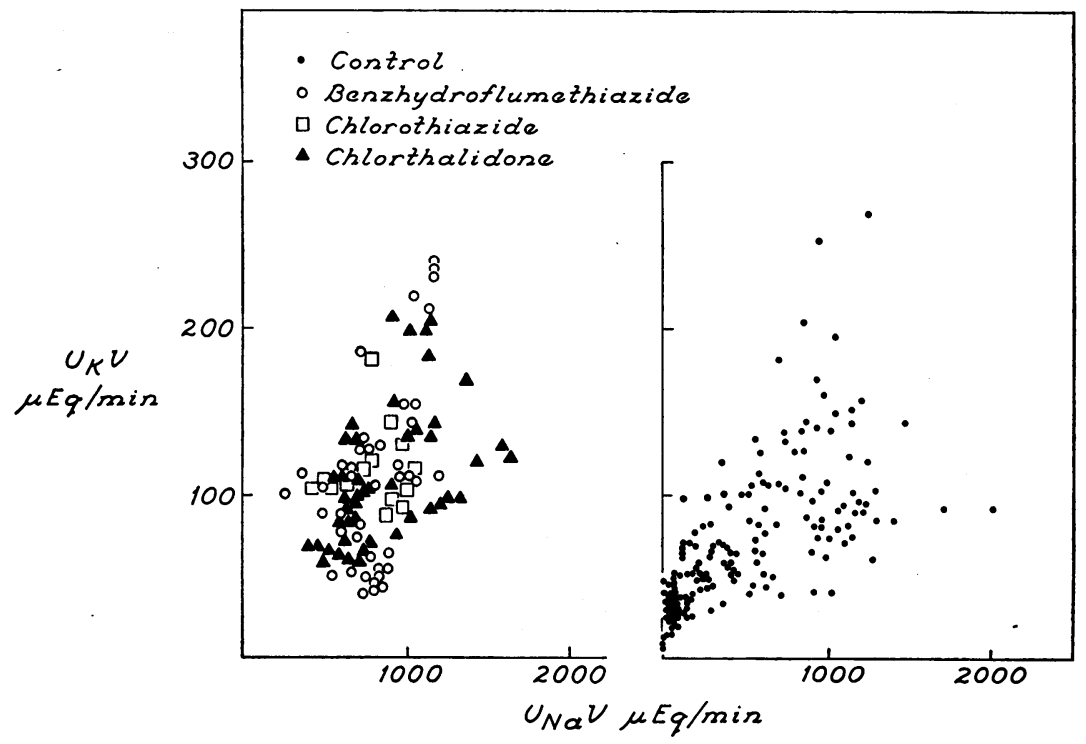

Fig. 5. The Changes in POTASSIUM EXCRETION AS RELATEd to SODIUM EXCRETION BEFORE AND AFTER THE ADMINISTRATION OF BENZHYDROFLUMETHIAZIDE, CHLOROTHIAZIDE, AND CHLORTHALIDONE. 

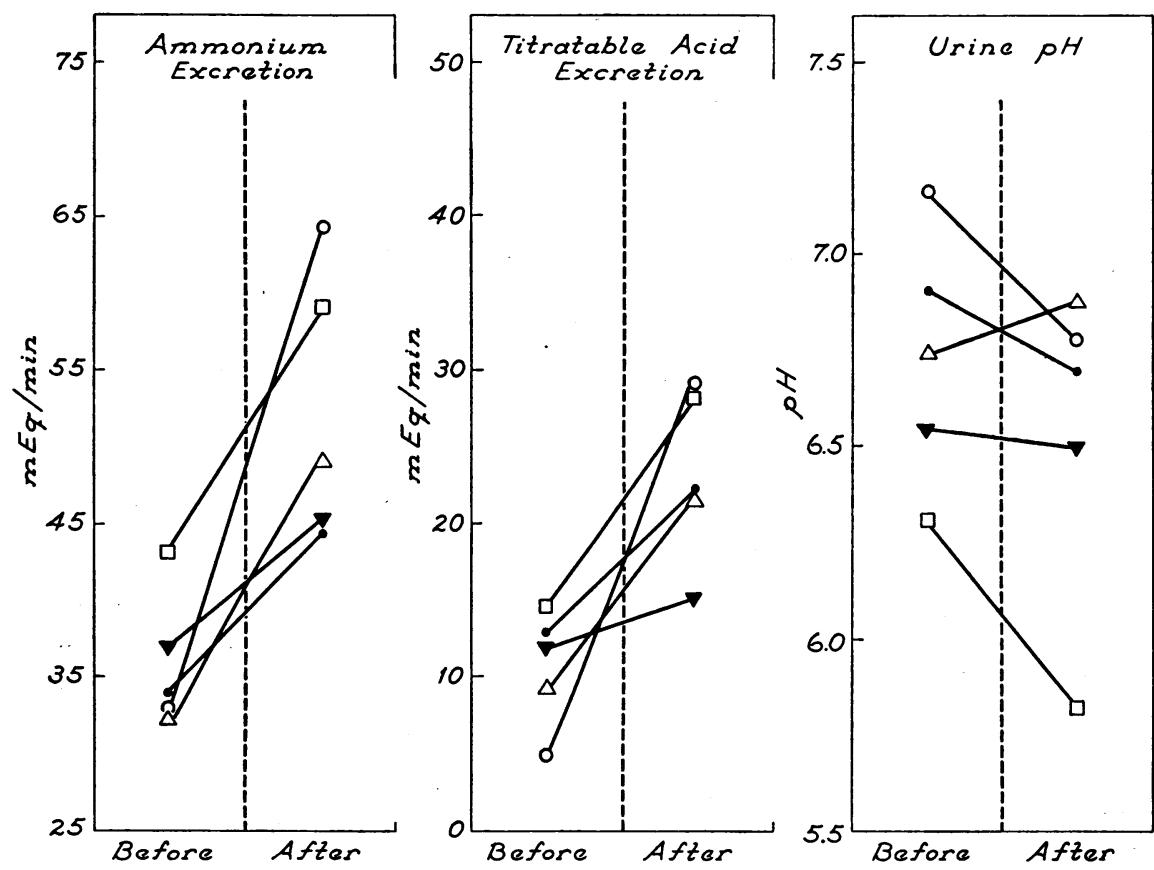

Fig. 6. Comparison of ammonium excretion, titratable acid, AND URINe PH in THE CONTROL PERIOD IMMEDIATELY PRECEDING FUROSEMIDE ADMINISTRATION (BEFORE) AND THE PERIOD AT THE PEAK OF DIURESIS (AFTER) IN FIVE INDIVIDUAL EXPERIMENTS.

lationship between $\mathrm{T}^{\mathrm{c}} \mathrm{H}_{2} \mathrm{O}$ and $\mathrm{C}_{\mathrm{osm}}$ following the administration of these diuretics was the same as that during the control studies (Figure 3 ).

Potassium secretion. In dogs prefed $\mathrm{KCl}$ for 1 week, net tubular secretion of potassium was produced by the infusion of isotonic potassium ferrocyanide. In all experiments the rise in sodium excretion following diuretic administration was accompanied by an increase in potassium excretion. In Table $\mathrm{V}$ two such experiments are presented. Because of the relatively short duration of action of furosemide it was possible to investigate whether an increased delivery of sodium to a distal sodiumpotassium exchange site may have masked an inhibition of potassium secretion by the diuretic. This was accomplished by the induction of sodium chloride diuresis at the termination of furosemide action in two dogs. It became evident from these experiments that at every level of sodium excretion during sodium chloride diuresis, the rate of potassium excretion was comparable to that during furosemide action (Table V, dog Med; Figure 4). Similarly, chlorothiazide and chlorthalidone had no effect on the relation between potassium and sodium excretion (Figure 5). None of the diuretics, therefore, exhibited any inhibitory effects on potassium excretion.

Acid excretion. In 5 dogs undergoing water diuresis, the administration of furosemide resulted in an increased excretion of ammonium ion and titratable acid, and a fall in urine $\mathrm{pH}$, with the exception of one experiment where the urine $\mathrm{pH}$ rose slightly (Figure 6). There is no evidence, therefore, of any inhibition of tubular acidification by furosemide.

\section{Discussion}

These studies demonstrate furosemide to be a diuretic whose action is rapid in onset ( 1 to $2 \mathrm{~min}$ utes), short in duration (about 60 minutes), and extremely potent. Whereas chlorthalidone, benzhydroflumethiazide, and chlorothiazide promote the excretion of no more than 10 to $15 \%$ of the filtered sodium, up to $38 \%$ can be excreted during furosemide diuresis.

The greater diuretic potency of furosemide is not simply the result of more intense inhibition of sodium transport at the same site in the nephron where other sulfonamide diuretics act. Studies on the pattern of water excretion clearly disclose 
that it has a different locus of action. Furosemide inhibited free water excretion by 50 to $60 \%$ and markedly reduced free water reabsorption, whereas the other sulfonamide diuretics inhibited $\mathrm{C}_{\mathrm{H}_{2} \mathrm{O}}$ but had no effect on $\mathrm{T}^{\mathrm{c}}{ }_{\mathrm{H}_{2} \mathrm{O}}$. Since the ascending limb of Henle's loop is the only site in the nephron where sodium reabsorption contributes to both $\mathrm{C}_{\mathrm{H}_{2} \mathrm{O}}$ and $\mathrm{T}^{\mathrm{c}} \mathrm{H}_{2} \mathrm{O}$, these results clearly establish this segment as a major site of furosemide action. In contrast, the absence of any inhibitory effect on $\mathrm{T}^{\mathrm{C}_{\mathrm{H}_{2} \mathrm{O}}}$ by the other diuretics suggests that they have no effect on the ascending limb of Henle's loop.

The ability of some diuretics such as chlorothiazide to inhibit $\mathrm{C}_{\mathrm{H}_{2} \mathrm{O}}$ without any effect on $\mathrm{T}^{\mathrm{e}} \mathrm{H}_{2} \mathrm{O}$ (11) and of other diuretics such as furosemide to inhibit both $\mathrm{C}_{\mathrm{H}_{2} \mathrm{O}}$ and $\mathrm{T}^{\mathrm{c}} \mathrm{H}_{2} \mathrm{O}$ suggests that there are two functionally distinct diluting segments. One diluting site, which may be termed the "medullary" diluting segment, occurs in the ascending limb of Henle's loop, contributes both to $\mathrm{T}^{\mathrm{c}} \mathrm{H}_{2} \mathrm{O}$ and $\mathrm{C}_{\mathrm{H}_{2} \mathrm{O}}$, and is clearly inhibited by furosemide. A second diluting site, the "cortical" diluting segment, contributes only to $\mathrm{C}_{\mathrm{H}_{2} \mathrm{O}}$ and is inhibited by agents such as chlorothiazide (11).

The fact that diuretics which act on the cortical diluting segment do not inhibit potassium and hydrogen secretion (Table V) suggests two possibilities concerning sodium reabsorption in the distal nephron. One possibility is that two different mechanisms mediate sodium reabsorption throughout the distal tubule, one system linking $\mathrm{Na}^{+}$and $\mathrm{Cl}^{-}$reabsorption and concerned with urinary dilution, and a second involved with the reabsorption of $\mathrm{Na}^{+}$in exchange for $\mathrm{K}^{+}$and $\mathrm{H}^{+}$, a process that would not alter urine osmotic pressure. An alternative possibility is that the sodium reabsorption concerned with urine dilution is located in a different anatomical site from that concerned with exchange. Micropuncture studies furnish strong support for this latter proposal. Potassium secretion appears to begin at the accessible portion of the distal convolution (just distal to the macula densa) and continues throughout the distal tubule (12). This area of the nephron does not appear to contribute to urinary dilution, since Gottschalk has shown that during water diuresis the fluid entering this segment is already maximally dilute with little or no further dilution along the remaining portion (13). These findings sup- port the proposal that the cortical portion of the distal nephron can be distinguished into a proximal segment (from the cortico-medullary junction to the macula densa) concerned with sodium chloride reabsorption and, therefore, urine dilution (cortical diluting segment), and a distal segment concerned with exchange. Our results also establish that not only chlorothiazide but also benzhydroflumethiazide and chlorthalidone reduce $\mathrm{C}_{\mathrm{H}_{2} \mathrm{O}}$ without influencing $\mathrm{T}^{\mathrm{c}} \mathrm{H}_{2} \mathrm{O}$ or $\mathrm{K}^{+}$secretion and therefore probably act on the cortical diluting segment.

Like chlorothiazide, chlorthalidone, and benzhydroflumethiazide, furosemide might also inhibit sodium transport in the cortical diluting segment. The absence of any inhibitory effect of furosemide on $\mathrm{K}^{+}$secretion is evidence against action in the later distal tubule.

It is doubtful, however, whether an action in the thick ascending limb alone could account for the enormous magnitude of furosemide diuresis, a finding that raises the question of an inhibitory effect in the proximal tubule as well. This is suggested by a rise in $\mathrm{C}_{\mathrm{H}_{2} \mathrm{O}}$ noted very early in the course of furosemide diuresis (Table IV, experiment 2). Two lines of evidence can be used to establish more convincingly a proximal tubular effect.

One means of assessing proximal tubular action has been to examine the effects of the drug during water diuresis. If it is assumed that during maximal water diuresis relatively little water is reabsorbed in the distal water-impermeable portions of the nephron, ${ }^{1}$ then the final urine volume can be considered a rough approximation of the volume entering the water-impermeable segments. Inhibition of sodium reabsorption in this distal waterimpermeable segment would then be expected to increase $\mathrm{C}_{\mathrm{osm}}$ and decrease $\mathrm{C}_{\mathrm{H}_{2} \mathrm{O}}$ but have little effect on urine flow. The finding in the present studies, therefore, that furosemide markedly increased urine volume in water diuresis (up to $300 \%$ increase in urine flow) would strongly suggest proximal tubular effect. It must be realized, however, that the above assumptions are not completely valid. Even during maximal water diuresis, the slightly hypertonic medullary inter-

\footnotetext{
1 Water-impermeable segments are taken to mean the ascending limb of Henle's loop, the distal convoluted tubule, and the collecting duct.
} 
stitium would promote the reabsorption of significant quantities of water from both the descending limb of Henle's loop and the collecting duct. Inhibition of sodium reabsorption in the ascending limb, therefore, would decrease medullary hypertonicity and thereby decrease the reabsorption of water in both the descending limb and collecting duct with a resultant increase in urine flow. Likewise, the modest increase in the rate of urine flow induced by the other sulfonamide diuretics during water diuresis could suggest a proximal tubular effect. The inhibition of sodium reabsorption in the distal convoluted tubule, however, would raise the osmolality of the fluid emerging from the distal convoluted tubule, thus making the transtubular osmolar gradient in' the collecting ducts less favorable for the back diffusion of free water, and a larger urine flow would result. Therefore, the increase in urine flow during water diuresis cannot be used by itself as evidence of proximal tubular action.

A second line of evidence that might be used to establish a proximal tubular effect is the maximal percentage of filtered water and filtered sodium excreted under the impact of the diuretic agent. On the basis of micropuncture studies on rats it has generally been assumed that only 15 to $25 \%$ of the glomerular filtrate escapes reabsorption in the proximal tubule. The excretion of as much as $45 \%$ of the glomerular filtrate after furosemide during water diuresis, therefore, might be used as evidence for a proximal tubular site of action. Recent micropuncture studies in the dog by Clapp, Watson, and Berliner (14), however, demonstrated that during water diuresis as much as $\mathbf{5 0}$ to $60 \%$ of the glomerular filtrate may escape reabsorption in the proximal convoluted tubule, and more importantly when $2.5 \%$ dextrose was infused, as was done in the present study, they found that the consequent hyperglycemia resulted in 70 to $80 \%$ of the glomerular filtrate escaping reabsorption in the proximal tubule. Therefore, the delivery of $45 \%$ of the glomerular filtrate in the present studies during water diuresis is not sufficient to establish a proximal site of action. In antidiuresis, however, on the basis of their data it can be concluded that probably not more than $20 \%$ of the glomerular filtrate is delivered out of the proximal tubule. In the present studies, during maximal antidiuresis the delivery of as much as $38 \%$ of the glomerular filtrate into the urine, particularly in the face of a fall in the glomerular filtration rate, is strong evidence that furosemide inhibits sodium reabsorption in the proximal tubule. Since the per cent of the GFR and filtered sodium excreted during the action of the other diuretics was comparatively small, it is not likely that they have a potent proximal effect.

The fact that the conventional sulfonamide diuretics appear to have at least a predominant effect in the distal nephron, yet augment sodium excretion to the same extent during hydration and hy-

TABLE VI

The effect of Pitressin infusion on sodium excretion during furosemide diuresis*

\begin{tabular}{|c|c|c|c|c|c|c|}
\hline $\begin{array}{c}\text { Experiment } \\
\text { no. }\end{array}$ & Time & GFR & $\mathbf{v}$ & $\mathrm{C}_{\mathrm{H}} \mathrm{O}$ & $\mathrm{UNaV}_{\mathrm{Na}}$ & $\frac{C_{N a}}{G F R} \times 100$ \\
\hline \multirow{7}{*}{ VI } & $\min$ & $\operatorname{ml} / \min$ & $\operatorname{ml} / \min$ & $m l / \min$ & $\mu E q / \min$ & \\
\hline & \multicolumn{6}{|c|}{$500 \mathrm{ml}$ water by gastric tube; $2.5 \%$ dextrose at $10 \mathrm{ml}$ per minute } \\
\hline & $\begin{array}{r}0-15 \\
15-30\end{array}$ & $\begin{array}{l}69 \\
62\end{array}$ & $\begin{array}{l}10.9 \\
11.8\end{array}$ & $\begin{array}{l}7.8 \\
9.4\end{array}$ & $\begin{array}{l}156 \\
197\end{array}$ & $\begin{array}{l}1.6 \\
2.3\end{array}$ \\
\hline & 301 & \multicolumn{5}{|c|}{$\begin{array}{l}\text { Furosemide } 5 \mathrm{mg} \text { per } \mathrm{kg} \text { iv and } 20 \mathrm{mg} \text { per } \mathrm{kg} \text { per hour; } 0.1 \mathrm{M} \mathrm{NaCl} \text { at } \\
20 \mathrm{ml} \text { per minute }\end{array}$} \\
\hline & $\begin{array}{l}30-45 \\
45-60 \\
60-75\end{array}$ & $\begin{array}{l}70 \\
62 \\
67\end{array}$ & $\begin{array}{l}24.1 \\
18.8 \\
19.7\end{array}$ & $\begin{array}{l}5.8 \\
4.0 \\
4.3\end{array}$ & $\begin{array}{l}2,437 \\
1,899 \\
2,012\end{array}$ & $\begin{array}{l}25.2 \\
22.6 \\
22.2\end{array}$ \\
\hline & \multicolumn{6}{|c|}{75 Pitressin $50 \mathrm{mU}$ per $\mathrm{kg}$ per minute } \\
\hline & $\begin{array}{c}75-90 \\
90-105 \\
105-120\end{array}$ & $\begin{array}{l}21 \\
49 \\
52\end{array}$ & $\begin{array}{r}6.1 \\
11.2 \\
13.3\end{array}$ & $\begin{array}{l}0.6 \\
0.2 \\
0.2\end{array}$ & $\begin{array}{r}692 \\
1,425 \\
1,753\end{array}$ & $\begin{array}{l}25.1 \\
21.4 \\
24.8\end{array}$ \\
\hline
\end{tabular}

* See Tables III and IV for abbreviations. 
dropenia, suggests that the same fraction of filtered sodium is delivered distally during water diuresis and antidiuresis. This raises some doubts regarding the validity of the observation (14) that water diuresis by itself inhibits markedly proximal sodium reabsorption. To check this point specifically (Table VI), furosemide was given during water diuresis and continued as a constant infusion at a rate of $20 \mathrm{mg}$ per $\mathrm{kg}$ per hour; about 22 to $25 \%$ of the filtered sodium was excreted. Pitressin was then given, reducing urine flow from 19.7 $\mathrm{ml}$ per minute to 6 to $13 \mathrm{ml}$ per minute. Nevertheless, the percent of the filtered sodium excreted into the urine did not fall, despite a sharp fall in GFR (probably a result of the massive injection of Pitressin). If water diuresis by itself inhibited proximal reabsorption, a decrease in sodium excretion during antidiuresis would have been anticipated.

These studies have important implications concerning the interpretation of the relation between $\mathrm{C}_{\text {osm }}$ and $\mathrm{C}_{\mathrm{H}_{2} \mathrm{O}}$ during the administration of agents that inhibit sodium transport. Goldstein, Levitt, Hauser, and Polimeros (15) have interpreted an increase in $\mathrm{C}_{\text {osm }}$ without any change in $\mathrm{C}_{\mathrm{H}_{2} \mathrm{O}}$ as evidence that mercurials act distal to the diluting segments (thick ascending limb and early distal tubule). They also recognized the alternative possibility, which they found less attractive, that these results might be produced by inhibition of sodium transport in both the proximal tubule and the diluting segments. The results with furosemide clearly indicate that not only was $\mathrm{C}_{\mathrm{H}_{2} \mathrm{O}}$ depressed by $50 \%$ after the administration of the drug but that it also exhibited the characteristics of a tubular maximum (Figure 1). This explains why $\mathrm{C}_{\mathrm{H}_{2} \mathrm{O}}$ can rise, remain unchanged, or fall as $\mathrm{C}_{\text {osm }}$ increases during furosemide diuresis, depending on whether $\mathrm{C}_{\mathrm{H}_{2} \mathrm{O}}$ during the control period is below, equal to, or greater than the maximal $\mathrm{C}_{\mathrm{H}_{2} \mathrm{O}}(\mathrm{Ta}-$ ble IV). Thus, it is possible for a drug such as furosemide that clearly acts in both the proximal tubule and the medullary diluting segment, but not in the distal tubule, to simulate the effect observed with mercurials. If the control $\mathrm{C}_{\mathrm{H}_{2} \mathrm{O}}$ is equal to the maximal $\mathrm{C}_{\mathrm{H}_{2} \mathrm{O}}$ during drug action (5 to $8 \mathrm{ml}$ per minute with furosemide), then the greatly increased sodium delivery out of the proximal tubule will augment $\mathrm{C}_{\mathrm{osm}}$ but not $\mathrm{C}_{\mathrm{H}_{2} \mathrm{O}}$. These different responses of $\mathrm{C}_{\mathrm{H}_{2} \mathrm{O}}$ after a diuretic is given point to the hazards of interpreting diuretic action from data obtained from a few control and diuretic periods and emphasize the need for defining the range of $\mathrm{C}_{\mathrm{H}_{2} \mathrm{O}}$ during control and diuretic periods over a wide range of $\mathrm{C}_{\text {osm }}$. It seems likely, therefore, that both mercury and furosemide can depress, leave unchanged, or augment $\mathrm{C}_{\mathrm{H}_{2} \mathrm{O}}$ as $\mathrm{C}_{\mathrm{osm}}$ increases by inhibiting sodium transport in both the proximal tubule and the diluting segment.

Earlier studies on chlorothiazide demonstrated that this drug would inhibit $\mathrm{C}_{\mathrm{H}_{2} \mathrm{O}}(1,11)$ but would not reduce $\mathrm{T}_{\mathrm{H}_{2} \mathrm{O}}(1,11,16)$ in $\operatorname{dog}$ and man. Our studies confirm the above findings, but also demonstrate that other existing sulfonamide diuretics, even a nonthiazide diuretic (chlorthalidone), exert their action in the same segment of the nephron. Moreover, this segment of the nephron, presumably the early distal tubule, is shown not to be an exchange site, since no inhibition of $\mathrm{K}^{+}$could be demonstrated. Furosemide, however, is here shown to be a unique sulfonamide diuretic. Not only is it significantly more potent than other sulfonamide diuretics, but it also exerts its major action in the loop of Henle and probably the proximal tubule as well. Only ethacrynic acid, a new diuretic belonging to an entirely new class of compounds, has action resembling, in part, that of furosemide. A recent publication on ethacrynic

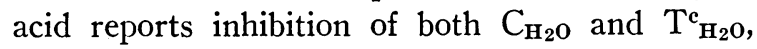
thus establishing an action in the loop of Henle (17). Moreover, Earley and Friedler (18) have demonstrated additive inhibitory effects of chlorothiazide and ethacrynic acid on $\mathrm{C}_{\mathrm{H}_{2} \mathrm{O}}$ and proposed that the former acted on the cortical, the latter on the medullary, diluting segment. In addition, a proximal tubular site of action could not be excluded (18).

It is concluded, therefore, that although furosemide is a potent inhibitor of sodium reabsorption, it has no inhibitory effect on either potassium or hydrogen ion secretion. Its major sites of action appear to be the proximal tubule and the ascending limb of Henle's loop.

\section{Summary}

The effects of a new diuretic, furosemide, were investigated and compared to other sulfonamide diuretics. In most instances there was a reduction in glomerular filtration rate that was not caused by salt depletion or hypotension. Furosemide in- 
hibited both solute-free water clearance $\left(\mathrm{C}_{\mathrm{H}_{2} \mathrm{O}}\right)$ and the reabsorption of solute-free water $\left(\mathrm{T}^{\mathrm{c}} \mathbf{H}_{2} \mathrm{O}\right)$, indicating a marked effect in the ascending limb of the loop of Henle. During antidiuresis as much as $38 \%$ of the glomerular filtrate was excreted, strongly suggesting a site of action in the proximal tubule. Finally, there was no inhibition of potassium secretion. The other sulfonamide diuretics, however, inhibited $\mathrm{C}_{\mathrm{H}_{2} \mathrm{O}}$ but not $\mathrm{T}^{\mathbf{c}}{ }_{\mathrm{H}_{2} \mathrm{O}}$, indicating an effect only on a cortical diluting segment; since no more than $10 \%$ of the glomerular filtrate was excreted, an action on the proximal tubules could not be identified.

$\mathrm{C}_{\mathrm{H}_{2} \mathrm{O}}$ during furosemide diuresis was depressed from a maximal control value of $15 \mathrm{ml}$ per minute to about $9 \mathrm{ml}$ per minute where it remained constant despite great increases in sodium excretion, thereby exhibiting the characteristics of a tubular maximum. This explains why furosemide and other diuretics can depress, leave unchanged, or augment $\mathrm{C}_{\mathrm{H}_{2} \mathrm{O}}$, depending on whether the control level of $\mathrm{C}_{\mathrm{H}_{2} \mathrm{O}}$ is above, at, or below the maximal $\mathrm{C}_{\mathrm{H}_{2} \mathrm{O}}$ during drug action.

\section{References}

1. Heinemann, H. O., F. E. Demartini, and J. H. Laragh. The effect of chlorothiazide on renal excretion of electrolytes and free water. Amer. J. Med. 1959, 26, 853.

2. Timmerman, R. J., F. R. Springman, and R. K. Thoms. Evaluation of furosemide, a new diuretic agent. Curr. ther. Res. 1964, 6, 88.

3. Orloff, J., H. N. Wagner, Jr., and D. G. Davidson. The effect of variations in solute excretion and vasopressin dosage on the excretion of water in the dog. J. clin. Invest. 1958, 37, 458.

4. Goldsmith, C., H. K. Beasley, P. J. Whalley, F. C. Rector, Jr., and D. W. Seldin. The effect of salt deprivation on the urinary concentrating mechanism in the dog. J. clin. Invest. 1961, 40, 2043.

5. Berliner, R. W., T. J. Kennedy, Jr., and J. G. Hilton. Renal mechanisms for excretion of potassium. Amer. J. Physiol. 1950, 162, 348.
6. Walser, M., D. G. Davidson, and J. Orloff. The renal clearance of alkali-stable inulin. J. clin. Invest. 1955, 34, 1520.

7. Smith, H. W., N. Finkelstein, L. Aliminosa, B. Crawford, and M. Graber. The renal clearances of substituted hippuric acid derivatives and other aromatic acids in dog and man. J. clin. Invest. 1945, 24, 388.

8. Conway, E. J. Microdiffusion Analysis and Volumetric Error, 4th ed. rev. London, C. Lockwood, 1957.

9. Heidland, A., K. Klütsch, and F. Suzuki. Nierenhämodynamik, Wasser- und Elektrolytausscheidung, nach 4-Chloro- $N$-(2-furylmethyl)-5-sulfamoyl-anthranilsäure. Arzneimittel-Forsch. 1964, 14, 713.

10. Goldsmith, C., F. C. Rector, Jr., and D. W. Seldin. Evidence for a direct effect of serum sodium concentration on sodium reabsorption. J. clin. Invest. 1962, 41, 850.

11. Earley, L. E., M. Kahn, and J. Orloff. The effects of infusions of chlorothiazide on urinary dilution and concentration in the dog. J. clin. Invest. 1961, $40,857$.

12. Malnic, G., R. M. Klose, and G. Giebisch. Micropuncture study of renal potassium excretion on the rat. Amer. J. Physiol. 1964, 206, 674.

13. Gottschalk, C. W. Micropuncture studies of tubular function in the mammalian kidney. Physiologist 1961, 4, 35.

14. Clapp, J. R., J. F. Watson, and R. W. Berliner. Osmolality, bicarbonate concentration, and water reabsorption in proximal tubule of the dog nephron. Amer. J. Physiol. 1963, 205, 273.

15. Goldstein, M. H., M. F. Levitt, A. D. Hauser, and D. Polimeros. Effect of meralluride on solute and water excretion in hydrated man: comments on site of action. J. clin. Invest. 1961, 40, 731.

16. Au, W. Y. W., and L. G. Raisz. Studies on the renal concentrating mechanism. I. Effect of diuretic agents. J. clin. Invest. 1960, 38, 1302.

17. Goldberg, M., K. K. McCurdy, E. L. Foltz, and L. W. Bluemle, Jr. Effects of ethracrynic acid (a new saluretic agent) on renal diluting and concentrating mechanisms: evidence for site of action in the loop of Henle. J. clin. Invest. 1964, 43, 201.

18. Earley, L. E., and R. M. Friedler. Renal tubular effects of ethacrynic acid. J. clin. Invest. 1964, 43, 1495. 